\title{
RESISTANCE OF RICE GENOTYPES TO THE BLAST FUNGUS AND THE ASSOCIATED BIOCHEMICAL CHANGES
}

\author{
ZAINAB A. KALBOUSH
}

Rice Pathology Department, Plant Pathology Research Insttitute, Agricultural Research Center, Egypt. Corresponding E-mail: zeinab.rrtc@yahoo.com

(Manuscript received 17 April 2019)

\begin{abstract}
$\mathrm{R}$ ice blast is the most important disease in Egypt and worldwide. The rice blast is caused by Pyricularia grisea this fungus can produce physiological races. Development of varietal resistance is the most effective way to control rice blast. This study was focused on identification of 20 isolates and evaluation of 21 rice genotypes for blast disease. Also, determining the biochemical changes after inoculation with the blast pathogen. The isolates were identified as five groups, IC group race the common followed by ID and only one race for each IA, IB and IF. Evaluation for genotypes showed that the first and second groups were resistant to blast infection. However, the third group showed 70 to $75 \%$ resistant. Biochemical changes included determination of antioxidant enzymes (Peroxidase (POX) and Ascorbate peroxidase (APX), defenserelated enzymes (Phenylalanine ammonia layase (PAL) and chitinase) and salicylic acid (SA). The different enzymes increased $96 \mathrm{~h}$ after inoculation with the pathogen and then decreased. The enzymes content was increased in inoculated seedling compared with the un-inoculated ones. The highest SA content was found in Giza 178 rice cultivar.

Keywords: Rice; Blast disease: Pyricularia grisea; Biochemical; varieties
\end{abstract}

\section{INTRODUCTION}

The most important and affective disease in rice crop worldwide is blast and the caused by P. grisea Sace., (Osman et al. 2002. and Scheuermann et al, 2012). This disease caused yield losses each year are enough to feed more than 60 million people (Scheuermann et al, 2012 and Divya et al, 2014). The causal fungus is Magnaporthe oryzae as ascomycetes, (anamorph Pyricularia oryzae) and M. grisea (anamorph $P$. grisea) a new species based on mating types for the fungus experiments (Samalova et al, 2014). The symptoms for this disease appear on vegetative parts, other parts during maturing stage of the crop. Identification of sources of resistance is necessary to manage the disease. New genotypes for host resistance are the best way to manage the different disease (Bonman and Nelson, 1992). The development of rice genotypes may provide new methods to control blast disease and increasing the approaches involved in defense to infection with P. grisea. The activation of defense response pathways is the target to make plants defend themselves against pathogens (Staskawicz et al, 1997). The activities of peroxidase (POX) and polyphenol oxidase (PPO) increased depending on the systemic induced resistance process. Catalyzing lignin formation is responsibility for these enzymes. Biosynthesis process as phytoalexins and phenols is responsible for phenylalanine 
ammonia lyase (PAL). $\beta-1,3$-glucanase and chitinase enzymes that belonging to pathogenesis-related proteins (PRPs) like PR-3 and PR-2 (van Loon et al., 2006). Systemic acquired resistance (SAR) and induced systemic resistance (ISR) are performed by these enzymes and all these enzymes shown linked with plant defense against pathogens in many pathosystem (Kini et al., 2000). Plants can induced some related antioxidant defense systems under biotic and abiotic stresses and that respond to decreasing damage effects of reactive oxygen species (ROS) (Panda, 2007). ROSscavenging enzymes may decrease the extent of oxidative damage and the levels of ROS in plant cell (Liang et al., 2003).

The aim of this work was to evaluate some rice genotypes for blast disease and identification some $P$. grisea isolates. Also, determination of some biochemical changes in rice seedling after inoculation with the $P$. grisea.

\section{MATERIALS AND METHODS}

The research work was established at rice pathology laboratory, greenhouse and farm at Kafr Elsheikh, Sakha, Rice Research and Training Center (RRTC) in two rice growing seasons (2016 and 2017).

Five rice lines from each cross i.e Giza 178 X CT9737-6-1-1-6-3P-M, these two parents resistant to blast disease, the second cross Sakha 101(susceptible) X Sakah 105 (resistant) and the third cross as Sakha 104 (susceptible) X WAB450-I-B-P-106-HB (susceptible). All the parents form Egyptian rice entries except CT9737-6-1-1-6-3P-M from Colombia (Table 1).

Blast sample collection: Rice blast Samples were collected during growing seasons (2015 and 2016) from Kafr El-Sheikh, Gharbia, Sharkia, Dakahlia, Damietta and Beheira governorates.

Table 1. Parentage, origin and grain type of evaluated rice genotypes

$\begin{array}{ccc}\text { Parents } & \text { Improved line } & \text { Type } \\ \text { Giza 178 (R*) } & \text { GZ10499-4-1-1-1 } & \\ \text { X } & \text { GZ10499-4-1-1-3 } & \text { IJ } \\ \text { CT9737-6-1-1-6-3P-M (R) } & \text { GZ10499-4-1-2-1 } & \\ & \text { GZ10499-9-1-1-1 } & \\ \text { Sakha 101 (S**) } & \text { GZ10501-2-6-3-2 } & \text { J } \\ \text { X } & \text { GZ10501-13-1-1-1 } & \\ \text { Sakha 105 (R) } & \text { GZ10501-15-2-1-2 } & \\ & \text { GZ10501-15-2-3-2 } & \\ \text { Sakha 104 (S) } & \text { GZ10501-15-3-1-8 } & \\ X & \text { GZ10686-2-1-2-1 } & \text { IJ } \\ \text { WAB450-I-B-P-106-HB (S) } & \text { GZ10686-2-1-2-3 } & \\ & \text { GZ10686-2-1-3-4 } & \\ & \text { GZ10686-11-1-1-3 } & \\ & \text { GZ10686-11-1-1-6 } & \end{array}$

*R, resistant; ${ }^{*} \mathrm{~S}$, susceptible. Indic Japonica (IJ) , Japonica (J) 


\section{Isolation of rice blast fungus:}

Typical blast lesions on leaves and panicles were isolated according to Shabana et al (2013). The isolates were grown and multiplied on banana medium under light florescent for ten days at $28^{\circ} \mathrm{C}$ for spore production. The isolates were collected at least 25 spores per microscopic at 10x objective (Shabana et al (2013).

Pathogenicity test and identification of blast physiological races: Fifteen rice lines, with their six parents as well as, eight international differential varieties (I.D.V) (Atkins et al, 1967) were used to evaluate and identify physiological blast races. All tested entries were inoculated with twenty isolates under greenhouse conditions. The tested entries were seeded in plastic trays ( $30 \times 20 \times 15 \mathrm{~cm}$ ). Each tray comprised 20 rows, with three replicates (Sehly et al, 2008). The trays were fertilized as recommended and then placed in the greenhouse at $28 \pm 2{ }^{\circ} \mathrm{C}$. The different seedling at 3 to 4 leaf stage (about 3-4 weeks after sowing) were inoculated with spore suspension at $\left(5 \times 10^{4}\right.$ spores $\left./ \mathrm{ml}\right)$ using electrical spray gun. The inoculated seedlings were kept in a moist chamber $95 \%$ R.H. and $28 \pm 2^{\circ} \mathrm{C}$ for $24 \mathrm{hr}$ and then put in greenhouse with similar conditions.

Disease assessment: Seven days after inoculation under greenhouse conditions, blast reactions as blast typical lesions were scored as 0-9 scale according to IRRI, 1996.

\section{Biochemical studies:}

Enzyme Activity: Rice leaves of different genotypes were collected after pathogen inoculation with the selected virulent race no.1 (IC-3) at various time intervals (48, 96 and $120 \mathrm{hr}$ ) and were quickly frozen in liquid nitrogen and stored at $-20^{\circ} \mathrm{C}$. Three replicates were maintained for each rice genotype.

Peroxidase (POX) activity: POX enzyme activity was determined according to Allam and Hollis (1972) and the methods described by and Srivastava (1987). POX activity was determined as changes in absorbance (optical density $/ \mathrm{min} / 0.5 \mathrm{~g}$ ) and activity of POX counted by /molar absorption coefficient $\left(U=26.6 \mathrm{mM}^{-1} \mathrm{~cm}^{-1}\right)$. The absorbance using a spectrophotometer was measured at $425 \mathrm{~nm}$.

Ascorbate peroxidase (APX) activity was assayed by the method according to Nakona and Asada (1981) and the absorbance was measured after $30 \mathrm{~s}$ of decreased at (290 $\mathrm{nm})$ spectrophotometer. Molar extinction was using by coefficient $(U=2.8 \mathrm{mM}-1$ $\mathrm{cm}^{-1}$ ) to determine the activity.

Phenylalanine ammonia layase activity (PAL) was determined by the method of Campos et al. (2004) and the absorbance was measured at $290 \mathrm{~nm}$. PAL activity was counted by ( $\mu$ moles of trans-cinnamic acid released / $\mathrm{min} / \mathrm{mg}$ proteins) under the specific condition. 
Chitinase assay: activity of chitinase was assessed according to Giri et al. (1998). The chitin powder was used as substrate (colloidal chitin) and prepared by the method described according to by Ried and Ogrud (1981). The chitinase activity was measured as O.D. at $540 \mathrm{~nm}$ ( $\mu \mathrm{g} \mathrm{N}$-acetyl glucosamine released / min / mg of protein).

Salicylic acid aAssay (SA): Samples of rice seedling were taken after 2 days from inoculated and non-inoculated with IC-3 race of $P$. grisea to assay the SA. Rice samples extraction and quantification of SA was conducted in the Food Technology Res. Institute, Agric. Res. Center according to (Goupy et al, 1999).

Data Analysis: Data of enzymes determination were subjected to randomized completely design (RCD) Duncan, (1955) .

\section{RESULTS AND DISCUSSION}

\section{Isolation of the causal organism of blast disease:}

Rice infected samples with blast collected from different rice cultivars and different locations during 2015-2016 seasons are shown in Table (2). Twenty P. grisea isolates were successfully isolated and purification was by the single spore technique. These isolates were identified to eleven races using the IDV under greenhouse conditions data in Table (3). Rice blast fungus, $P$. grisea is known to be highly variable (Sehly et al. 2008). Many investigators studied the physiological races of the fungus at different rice-growing areas (Arafa, 2012 and Shabana et al, 2013).

\section{Pathogenicity test and race identification}

Results indicated that the twenty isolates were identified as five groups using the IDV (Table 3). Thirteen isolates were identified as group IC, while four isolates were identified as group ID race. On the other hand, isolates no 3, 7 and 18 were identified as IB, IA and IF group races. These results are agreed with the findings of (Sehly et al, 2008; Arafa 2012 and Shabana et al, 2013) that showed the distribution of races at different governorates. The virulence of the obtained isolates was determined by inoculating the fifteen rice lines, with their six parents of each individual isolate. The twenty isolates except isolates no. 9, 11 and 14 were virulent to Sakha 101(the commercial rice cv) (Table 4). While, only 13 isolates were virulent on Sakha 104 and no isolates were able to infect Giza178 or Sakha 105 rice cv (Table 4). All lines were resistant for the blast fungus except GZ10686-2-1-2-3 and GZ10686-11-1-1-3 that were susceptible to five isolates, while, GZ10686-2-1-3-4 was susceptible to six isolates. These results will be considered in developing resistant genotypes which is the most important method for control rice blast disease. This approach is friendly for environment and disease mangement (Bonman et al, 1992). Moldenhauer et al. (1992) evaluated nine parents to rice blast races IB-49 and IC-17. Parents, generally 
showed resistance for rice blast fungus races (IC-17 and IB-49), that was monogenic and dominant under the natural conditions. Wang et al. (2007) inoculated 141 rice entries with blast race IC-17 to verify the presence of Pi-ta gene, 41 accessions were resistant. Sedeek et al. (2015) evaluated 10 promising lines and their parents for rice blast disease. The breeding lines were resistant to rice blast under artificial inoculation in greenhouse and field condition, but Sakha 101were susceptible. Fang et al. (2017) reported that rice varieties were resistant to different races of $M$. oryzae in Australia. The variety SHZ-2 exhibited a resistant reaction to all five races, while, BR-IRGA-409, Ceysvoni, Rikuto Norin 20, NTR587 and Kyeema, were resistant to M. oryza at least three races.

Table 2.Source of Pyricularia grisea isolates collected in 2015 and 2016 seasons

\begin{tabular}{|c|c|c|c|c|c|}
\hline $\begin{array}{c}\text { Isolate } \\
\text { no. } \\
\end{array}$ & Governorate & District & Rice cultivar/line & Year & Race \\
\hline 1 & Kafr El-Sheikh & Desouq & Sakha 101 & 2015 & IC-3 \\
\hline 2 & Kafr El-Sheikh & Desouq & Sakha 101 & 2016 & IC-3 \\
\hline 3 & Kafr El-Sheikh & Sakha & Sakha 104 & 2015 & IB-47 \\
\hline 4 & Kafr El-Sheikh & Foaa & Sakha 101 & 2015 & IC-3 \\
\hline 5 & Kafr El-Sheikh & Kafr El-Sheikh & Sakha 101 & 2016 & IC-11 \\
\hline 6 & Kafr El-Sheikh & Desouq & Sakha 104 & 2016 & IC-9 \\
\hline 7 & Kafr El-Sheikh & Sakha & Sakha 101 & 2016 & IA-67 \\
\hline 8 & Dakahlia & Talkha & Sakha 101 & 2015 & ID-11 \\
\hline 9 & Dakahlia & Kafr Saad & Sakha 104 & 2015 & IC-3 \\
\hline 10 & Dakahlia & Dekerns & Sakha 101 & 2016 & ID-3 \\
\hline 11 & Dakahlia & Dekerns & Sakha 104 & 2016 & IC-11 \\
\hline 12 & Dakahlia & Talkha & Sakha 101 & 2016 & IC-11 \\
\hline 13 & Beheira & Elebrahimyia & Sakha 104 & 2015 & ID-15 \\
\hline 14 & Beheira & Mahmoudia & Sakha 101 & 2015 & ID-11 \\
\hline 15 & Beheira & Kafr El-Dawar & Sakha 101 & 2015 & IC-1 \\
\hline 16 & Beheira & Itai-El-Barood & $\mathrm{BL}-1$ & 2016 & IC-11 \\
\hline 17 & Beheira & Itai-El-Barood & Giza171 & 2016 & IC-3 \\
\hline 18 & Beheira & Kafr El-Dawar & Reiho & 2016 & IF-1 \\
\hline 19 & Damietta & Zarka & Sakha 101 & 2016 & IC-3 \\
\hline 20 & Sharkia & Kafr Saker & Sakha 101 & 2016 & IC-7 \\
\hline
\end{tabular}


Table 3. Rice blast reactions on the international differential varieties (IDVs) tested under greenhouse condtions

\begin{tabular}{|c|c|c|c|c|c|c|c|c|c|c|c|c|c|c|c|c|c|c|c|c|c|}
\hline \multirow{2}{*}{ IDV } & \multirow{2}{*}{$\begin{array}{l}\text { Group } \\
\text { races }\end{array}$} & \multicolumn{20}{|c|}{ Isolate number/ Reaction } \\
\hline & & 1 & 2 & 3 & 4 & 5 & 6 & 7 & 8 & 9 & 10 & 11 & 12 & 13 & 14 & 15 & 16 & 17 & 18 & 19 & 20 \\
\hline $\begin{array}{l}\text { Raminad } \\
\text { str.3 }\end{array}$ & IA & $\mathrm{R}$ & $\mathrm{R}$ & $\mathrm{R}$ & $\mathrm{R}$ & $\mathrm{R}$ & $\mathrm{R}$ & $\mathrm{S}$ & $\mathrm{R}$ & $\mathrm{R}$ & $\mathrm{R}$ & $\mathrm{R}$ & $\mathrm{R}$ & $\mathrm{R}$ & $\mathrm{R}$ & $\mathrm{R}$ & $\mathrm{R}$ & $\mathrm{R}$ & $\mathrm{R}$ & $\mathrm{R}$ & $\mathrm{R}$ \\
\hline Zenith & IB & $\mathrm{R}$ & $\mathrm{R}$ & $\mathrm{S}$ & $\mathrm{R}$ & $\mathrm{R}$ & $\mathrm{R}$ & $\mathrm{R}$ & $\mathrm{R}$ & $\mathrm{R}$ & $\mathrm{R}$ & $\mathrm{R}$ & $\mathrm{R}$ & $\mathrm{R}$ & $\mathrm{R}$ & $\mathrm{R}$ & $\mathrm{R}$ & $\mathrm{R}$ & $\mathrm{R}$ & $\mathrm{R}$ & $\mathrm{R}$ \\
\hline NP-125 & IC & $\mathrm{S}$ & $\mathrm{S}$ & $\mathrm{R}$ & $\mathrm{S}$ & $\mathrm{S}$ & $\mathrm{S}$ & $\mathrm{S}$ & $\mathrm{R}$ & $\mathrm{S}$ & $\mathrm{R}$ & $S$ & $\mathrm{~S}$ & $\mathrm{R}$ & $\mathrm{R}$ & $\mathrm{S}$ & $\mathrm{S}$ & $\mathrm{S}$ & $\mathrm{R}$ & $S$ & $\mathrm{~S}$ \\
\hline Usen & ID & $\mathrm{HS}$ & $\mathrm{s}$ & $\mathrm{S}$ & $\mathrm{S}$ & HS & $\mathrm{S}$ & $\mathrm{S}$ & $\mathrm{HS}$ & HS & $S$ & HS & $S$ & $\mathrm{HS}$ & $\mathrm{S}$ & $S$ & HS & $S$ & $\mathrm{R}$ & $S$ & $S$ \\
\hline Dular & IE & $S$ & $S$ & $\mathrm{R}$ & $S$ & $\mathrm{R}$ & $\mathrm{R}$ & $\mathrm{S}$ & $\mathrm{R}$ & $S$ & $\mathrm{~S}$ & $\mathrm{R}$ & $\mathrm{R}$ & $\mathrm{R}$ & $\mathrm{R}$ & $\mathrm{S}$ & $\mathrm{R}$ & $S$ & $\mathrm{R}$ & $S$ & $S$ \\
\hline Kanto 51 & IF & $S$ & $S$ & $\mathrm{R}$ & $\mathrm{S}$ & $S$ & $S$ & $\mathrm{~S}$ & $\mathrm{~S}$ & $S$ & $\mathrm{~S}$ & $S$ & $S$ & $\mathrm{R}$ & $S$ & $S$ & $\mathrm{~S}$ & $\mathrm{~S}$ & $S$ & $S$ & $\mathrm{R}$ \\
\hline CI $8970 \mathrm{~s}$ & IG & $\mathrm{R}$ & $\mathrm{R}$ & $\mathrm{R}$ & $\mathrm{R}$ & $\mathrm{R}$ & $S$ & $\mathrm{R}$ & $\mathrm{R}$ & $\mathrm{R}$ & $\mathrm{R}$ & $\mathrm{R}$ & $\mathrm{R}$ & $\mathrm{R}$ & $\mathrm{R}$ & $S$ & $R$ & $\mathrm{R}$ & $\mathrm{S}$ & $\mathrm{R}$ & $\mathrm{R}$ \\
\hline Caloro & $\mathrm{IH}$ & $\mathrm{S}$ & $S$ & $\mathrm{~S}$ & HS & HS & HS & $S$ & $\mathrm{HS}$ & $S$ & $\mathrm{~S}$ & HS & HS & $\mathrm{HS}$ & $S$ & HS & $S$ & HS & $S$ & HS & HS \\
\hline Race & & IC-3 & IC-3 & $\begin{array}{l}\text { IB- } \\
47\end{array}$ & IC-3 & $\begin{array}{l}\text { IC- } \\
11\end{array}$ & IC-9 & $\begin{array}{l}\text { IA- } \\
67\end{array}$ & $\begin{array}{l}\text { ID- } \\
11\end{array}$ & IC-3 & ID-3 & $\begin{array}{l}\text { IC- } \\
11\end{array}$ & $\begin{array}{l}\text { IC- } \\
11\end{array}$ & $\begin{array}{l}\text { ID- } \\
15\end{array}$ & $\begin{array}{l}\text { ID- } \\
11\end{array}$ & IC-1 & $\begin{array}{l}\text { IC- } \\
11\end{array}$ & IC-3 & IF-1 & IC-3 & IC-7 \\
\hline
\end{tabular}

* Reactions: R = resistant (1-2), MR = moderately resistant (3), S = susceptible (4-6), HS = highly susceptible (7-9). 
Table 4. Reaction of 21 rice entries inoculated with 20 Pyricularia grisea isolates under greenhouse conditions

\begin{tabular}{|c|c|c|c|c|c|c|c|c|c|c|c|c|c|c|c|c|c|c|c|c|c|}
\hline \multirow[t]{2}{*}{ No. } & \multirow{2}{*}{ Cultivar/entry } & \multicolumn{20}{|c|}{ Isolate number/ Reaction } \\
\hline & & IC- & IC- & IB- & IC- & IC- & IC- & IA- & ID- & IC- & ID- & IC- & IC- & ID- & ID- & IC- & IC- & IC- & IF- & IC- & IC- \\
\hline 1 & Giza 178 & $R$ & $\mathrm{R}$ & $\mathrm{R}$ & $\mathrm{R}$ & $\mathrm{R}$ & $\mathrm{R}$ & $\mathrm{R}$ & $\mathrm{R}$ & $\mathrm{R}$ & $R$ & $\mathrm{R}$ & $R$ & $\mathrm{R}$ & $\mathrm{R}$ & $\mathrm{R}$ & $\mathrm{R}$ & $\mathrm{R}$ & $\mathrm{R}$ & $\mathrm{R}$ & $\mathrm{R}$ \\
\hline 2 & СТ9739-6-1-1-6- & $R$ & $\mathrm{R}$ & $\mathrm{R}$ & $\mathrm{R}$ & $\mathrm{R}$ & $\mathrm{R}$ & $\mathrm{R}$ & $\mathrm{R}$ & $\mathrm{R}$ & $\mathrm{R}$ & $\mathrm{R}$ & $\mathrm{R}$ & $\mathrm{R}$ & $\mathrm{R}$ & $\mathrm{R}$ & R & $\mathrm{R}$ & $\mathrm{R}$ & $\mathrm{R}$ & $\mathrm{R}$ \\
\hline 3 & GZ10499-4-1-1-1 & MR & MR & $\mathrm{R}$ & $\mathrm{R}$ & MR & $R$ & $\mathrm{R}$ & $R$ & $\mathrm{R}$ & MR & $\mathrm{R}$ & $R$ & $\mathrm{R}$ & $\mathrm{R}$ & $\mathrm{R}$ & $\mathrm{R}$ & $\mathrm{R}$ & R & $\mathrm{R}$ & $\mathrm{R}$ \\
\hline 4 & GZ10499-4-1-1-3 & $\mathrm{R}$ & $R$ & $\mathrm{R}$ & $\mathrm{R}$ & $\mathrm{R}$ & $R$ & $\mathrm{R}$ & $\mathrm{R}$ & $R$ & $\mathrm{R}$ & $R$ & $\mathrm{R}$ & $\mathrm{R}$ & $R$ & $\mathrm{R}$ & $\mathrm{R}$ & $R$ & R & $R$ & $\mathrm{R}$ \\
\hline 5 & GZ10499-4-1-2-1 & MR & $\mathrm{R}$ & $R$ & $\mathrm{R}$ & $\mathrm{R}$ & $R$ & $\mathrm{R}$ & $\mathrm{R}$ & $\mathrm{R}$ & $R$ & $R$ & $\mathrm{R}$ & $\mathrm{R}$ & $\mathrm{R}$ & MR & $\mathrm{R}$ & $\mathrm{R}$ & $\mathrm{R}$ & $\mathrm{R}$ & $R$ \\
\hline 6 & GZ10499-9-1-1-1 & $R$ & $R$ & $\mathrm{R}$ & $\mathrm{R}$ & MR & $R$ & MR & $R$ & $R$ & MR & $\mathrm{R}$ & MR & $\mathrm{R}$ & $R$ & $\mathrm{R}$ & R & R & R & $\mathrm{R}$ & $R$ \\
\hline 7 & GZ10499-12-1-1-1 & MR & MR & MR & $R$ & $M R$ & MR & MR & R & MR & $R$ & MR & MR & $R$ & $R$ & MR & $\mathrm{R}$ & R & MR & $\mathrm{R}$ & $M R$ \\
\hline 8 & Sakha 101 & S & S & $\mathrm{s}$ & S & $\mathrm{S}$ & $\mathrm{S}$ & HS & HS & $R$ & HS & $R$ & HS & $\mathrm{S}$ & $R$ & HS & S & $\mathrm{HS}$ & $\mathrm{S}$ & HS & $\mathrm{HS}$ \\
\hline 9 & Sakha 105 & R & $\mathrm{R}$ & $R$ & $R$ & $\mathrm{R}$ & $R$ & MR & $\mathrm{R}$ & $R$ & $R$ & $R$ & $R$ & $\mathrm{R}$ & $R$ & $\mathrm{R}$ & R & $R$ & R & $\mathrm{R}$ & $\mathrm{R}$ \\
\hline 10 & GZ10501-2-6-3-2 & $R$ & $\mathrm{R}$ & $\mathrm{R}$ & $R$ & $\mathrm{R}$ & $\mathrm{R}$ & $\mathrm{R}$ & $R$ & $\mathrm{R}$ & $R$ & $R$ & $R$ & $\mathrm{R}$ & $R$ & $\mathrm{R}$ & $\mathrm{R}$ & $\mathrm{R}$ & $\mathrm{R}$ & $\mathrm{R}$ & $\mathrm{R}$ \\
\hline 11 & GZ10501-13-1-1-1 & $\mathrm{R}$ & $R$ & $\mathrm{R}$ & $R$ & $R$ & $R$ & $\mathrm{R}$ & $R$ & $R$ & $R$ & $R$ & R & $R$ & $R$ & $R$ & $\mathrm{R}$ & R & $\mathrm{R}$ & $\mathrm{R}$ & $R$ \\
\hline 12 & GZ10501-15-2-1-2 & R & $\mathrm{R}$ & $\mathrm{R}$ & $\mathrm{R}$ & $\mathrm{R}$ & $\mathrm{R}$ & $\mathrm{R}$ & $\mathrm{R}$ & $\mathrm{R}$ & $R$ & $\mathrm{R}$ & R & $\mathrm{R}$ & $R$ & $\mathrm{R}$ & $\mathrm{R}$ & $\mathrm{R}$ & $\mathrm{R}$ & $\mathrm{R}$ & $\mathrm{R}$ \\
\hline 13 & GZ10501-15-3-3-2 & $R$ & $R$ & $\mathrm{R}$ & $\mathrm{R}$ & $\mathrm{R}$ & $R$ & $\mathrm{R}$ & $R$ & $R$ & $R$ & $R$ & $R$ & $R$ & $R$ & $R$ & $\mathrm{R}$ & R & $R$ & $\mathrm{R}$ & $R$ \\
\hline 14 & GZ10501-15-3-1-8 & R & R & $\mathrm{R}$ & $R$ & $\mathrm{R}$ & $R$ & $\mathrm{R}$ & $R$ & $R$ & $R$ & $R$ & $R$ & $R$ & R & $\mathrm{R}$ & $\mathrm{R}$ & $\mathrm{R}$ & R & $\mathrm{R}$ & $R$ \\
\hline 15 & Sakha 104 & HS & $\mathrm{HS}$ & HS & S & HS & HS & $\mathrm{R}$ & $R$ & HS & $R$ & HS & S & $S$ & $R$ & $\mathrm{R}$ & $\mathrm{HS}$ & S & HS & $\mathrm{R}$ & $R$ \\
\hline 16 & WAB450-I-B-P- & S & S & $R$ & $R$ & $\mathrm{~S}$ & $R$ & $\mathrm{~S}$ & $\mathrm{R}$ & $\mathrm{R}$ & $R$ & HS & $R$ & $R$ & $R$ & $\mathrm{R}$ & $\mathrm{S}$ & $\mathrm{R}$ & $\mathrm{R}$ & $\mathrm{R}$ & $\mathrm{R}$ \\
\hline 17 & GZ10686-2-1-2-1 & $R$ & $R$ & $R$ & $R$ & $\mathrm{R}$ & $R$ & $\mathrm{R}$ & $R$ & $R$ & $R$ & $R$ & R & $\mathrm{R}$ & $R$ & $\mathrm{R}$ & $\mathrm{R}$ & R & $\mathrm{R}$ & $\mathrm{R}$ & $R$ \\
\hline 18 & GZ10686-2-1-2-3 & S & $R$ & s & $\mathrm{R}$ & $\mathrm{R}$ & S & $\mathrm{R}$ & $R$ & S & $R$ & $\mathrm{~S}$ & R & MR & $R$ & $R$ & MR & R & R & $\mathrm{R}$ & $\mathrm{R}$ \\
\hline 19 & GZ10686-2-1-3-4 & S & $\mathrm{R}$ & S & $\mathrm{R}$ & $\mathrm{R}$ & S & $\mathrm{R}$ & $\mathrm{R}$ & S & $R$ & S & $\mathrm{R}$ & $\mathrm{S}$ & $\mathrm{R}$ & $\mathrm{R}$ & $\mathrm{MR}$ & $\mathrm{R}$ & $\mathrm{R}$ & $\mathrm{R}$ & $\mathrm{R}$ \\
\hline 20 & GZ10686-11-1-1-3 & $S$ & $R$ & S & $R$ & $\mathrm{R}$ & S & $\mathrm{R}$ & $R$ & S & $R$ & S & $R$ & MR & $R$ & $R$ & MR & R & $R$ & $\mathrm{R}$ & $R$ \\
\hline 21 & GZ10686-11-1-1-6 & R & R & R & $R$ & $R$ & R & $R$ & $R$ & $R$ & R & $R$ & $R$ & $R$ & R & $R$ & $R$ & $R$ & R & $R$ & $R$ \\
\hline
\end{tabular}

* Reactions: $\mathrm{R}$ = resistant (1-2), MR = moderately resistant (3), $\mathrm{S}=$ susceptible (4-6), HS = highly susceptible (7-9) 


\section{Activity of antioxidative enzymes:}

Peroxidase activity (POX) ranged from 460.2 to $1510.0 \mu$ moles $\mathrm{H}_{2} \mathrm{O}_{2}$ oxidized in the inoculated seedling (Fig. 1). While, in un-inoculated leaf samples, the POX activity ranged from 101.0 to $516.0 \mu$ moles $\mathrm{H}_{2} \mathrm{O}_{2}$ oxidized. The maximum increase in POX activity was recorded at $96 \mathrm{hr}$ after inoculation and then decreased. The highest activity for POX significantly induced in blast resistant genotype) in GZ 10686-2-1-2-1, GZ 1068-11-1-1-6, GZ 10501-13-1-1-1 and GZ10501-15-3-3-2. The least level of induction was recorded in Sakha 104 and 101 (231.4 and $250.0 \mu$ moles, respectively), a susceptible rice cultivars. POX enzyme in healthy plants may be due to their presence in healthy plant tissues as constitutive enzymes. The second messengers in resistance mechanisms is reactive oxygen species (ROS), it is considered indicator to interfere with other important signaling molecules and the defense-related genes (Chen et al, 2014). Enzymatic antioxidants such as peroxidase (POX) can control production of ROS during plant -pathogen interaction (Barna et al, 2012). Activation of POX enzyme in the various substrates using hydrogen peroxide can catalyzes oxido-reduction and elimination of ROS. POX may acts as either $\mathrm{H}_{2} \mathrm{O}_{2}$ scavenger or generator depending on physiological condition (Almagro et al, 2009). POX activity induced may be elimination the generation of ROS and control it (Rahman and Wenner, 2014) or appear toxicity toward invading pathogen (Torres 2006).

APX activity profile ranged from 105.6 to $254.8 \mu$ moles ascorbate oxidized (ASO) in the un-inoculafrom between 380.0 to $1663.2 \mu$ moles (ASO) (Fig. 2). APX activity recorded higher levels after $96 \mathrm{hr}$ of inoculation with the blast pathogen. There were no significant difference among Giza 105, Giza 178 and CT9739-6-1-1-63p-M (1663.2, 1523.0 and $1492.4 \mu$ moles (ASO), respectively. These genotypes proved to be the highest activate for APX and resistance to blast disease. Sakha 101 and 104 recorded lower levels of APX after 96h. APX activity significantly increased in blast resistant genotypes after 48 and $96 \mathrm{~h}$ and then decreased. APX activity is the one of the most important antioxidant enzymes, practically all sub-cellular compartments. Agrawal (2003) suggested that cytosolic APX genes are up regulated upon wounding and plays as a protective role against pathogens in rice. These enzymes may arrest the ROS production with higher levels in resistant rice genotypes compared with susceptible ones. These results suggest the critical role of early $\mathrm{O}_{2}-$ and $\mathrm{H}_{2} \mathrm{O}_{2}$ accumulation; also POX and APX may help to lignification as defense mechanism involved in basal resistance in our pathosystem. Using $\mathrm{POX}$ for $\mathrm{H}_{2} \mathrm{O}_{2}$ to has oxidized for some phenolics constituents to lignin (Sharma et al, 2012; Nikraftar et al, 2013). 


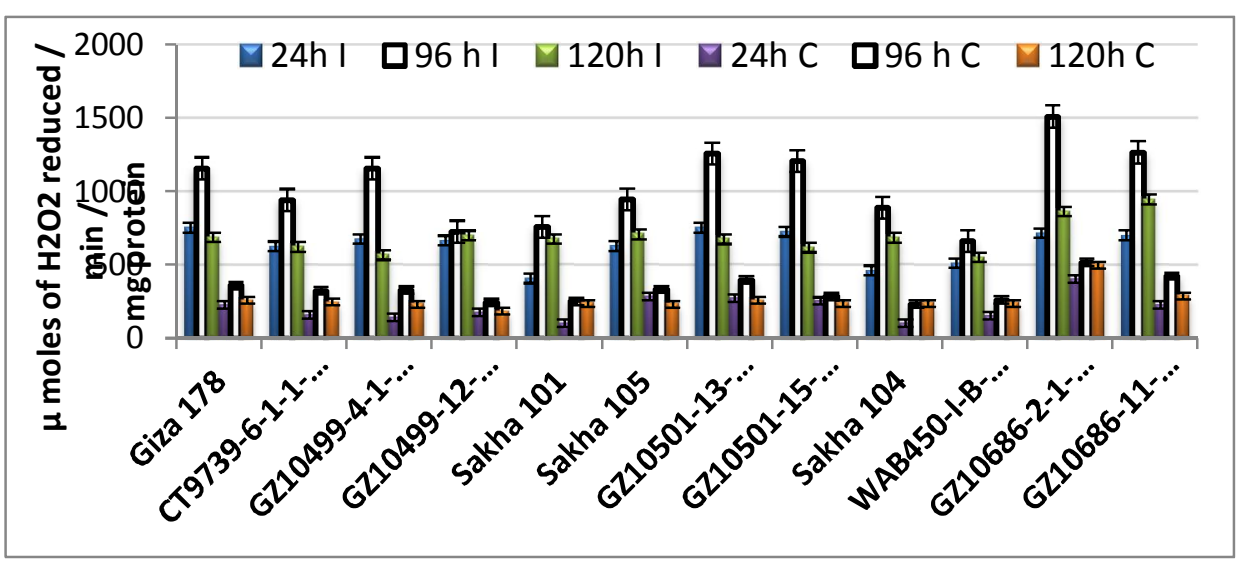

Fig. 1. Levels of peroxidase activity in leaves of rice genotypes 48,96 and $120 \mathrm{hr}$ after artificial inoculation with $P$. oryzae. The bar represent standard error (SE \pm ) of mean $(n=3)$ at Duncan test $(P \leq 0.05=153.7)$ probability.

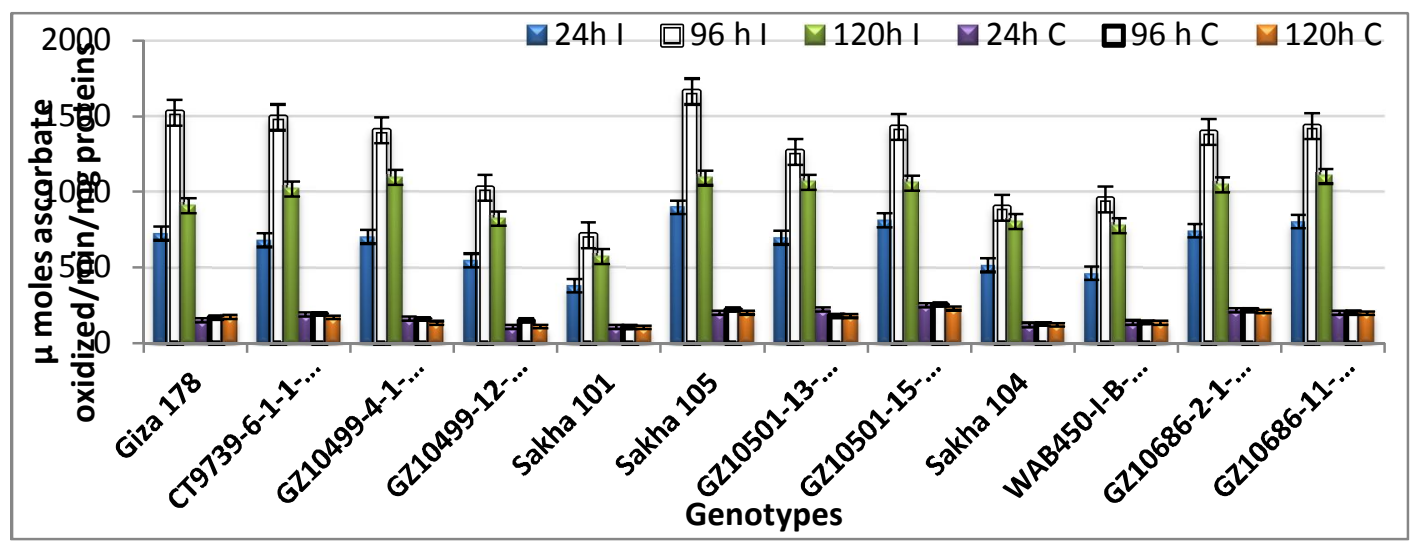

Fig. 2. Levels of ascorbate peroxidase activity in leaves of rice genotypes 48,96 and 120 hr after artificial inoculation with $P$. oryzae. The bar represent standard error (SE \pm ) of mean $(n=3)$ at Duncan test $(P \leq 0.05=212.8)$ probability.

\section{Profile activity of defense-related enzymes}

The PAL activity profile of the 21 rice genotypes ranged from 0.6 to $1.83 \mu$ moles cinnamic acid in un-inoculated while it ranged from 1.07 and $5.20 \mu$ moles cinnamic acid in the inoculated seedling (Fig. 3). The PAL activity was significantly higher in GZ10501-13-1-1-1 after $96 \mathrm{hr}$ and then decreased after 120hr (5.20 and $3.527 \mu$ moles cinnamic acid). The PAL increased in inoculated resistant genotypes (GZ10686-11-1-16 followed by Sakha 105 and GZ 10501-15-3-3-2), and the low level was recorded in Sakha 101 blast susceptible (Fig. 3). Also, PAL activity constitutively recorded higher levels in three groups of genotypes. New proteins are formed in interactions between plant-pathogens direct or indirect effect in plant resistance to pathogen called as pathogenesis- related (PR) proteins (Jones \& Dangl, 2006). Some PR protein like $\beta$ glucosidase, PAL and chitinase were found in plant resistance against pathogens 
fungal (Kini et al, 2000). PAL catalysis is responsible for biosynthesis of the phenyl propanoid pathway and involved in the synthesis of twice phytoalexin and lignin. These phytoalexin and lignin can prevent penetration by the pathogen for cell wall (Dixon, 2001). Zhang and Yu (1987) found that increase the level of PAL in rice cultivars (six) was different in level of resistance to M. oryzae. Hsieh et al. (2010) reported that PAL activity in resistant cultivars was higher than in susceptible ones which may be due to difficult of site infection and preventing pathogen to entry the host plant.

The activity of chitinase ranged from 4.4 and $33.7 \mu$ gNAG in un- inoculated 21 rice genotypes. The activity of chitinase increased after inoculation with $P$. oryzae from 8.3 to $55.0 \mu \mathrm{g}$ NAG (Fig. 4). The activity of chitinase was highert in inoculated GZ10-686-11-1-1-6 and Giza 178 as (55.0 and 53.8 $\mu$ g NAG). While, WAB450-I-B-P106-HP recorded lower activity after inoculation compared to other rice genotypes. Chitinase activity was higher in infected and wounded plants compared with healthy ones (Boller, 1988). Plants can use some receptors recognized to defend themselves from microbial pathogens. These receptors recognize pathogen-associated molecular patterns and activate signaling pathways that lead to immunity. In rice the chitin elicitor binding protein recognizes, oligosaccharides and released from the cell walls of fungal pathogens. Here, we show this first line of plant defense against rice blast fungus $M$. oryzae by secreting an effector protein, secreted LysM Protein1 (Slp1), during invasion of new rice cells. Accumulation of the Slp1 at the interface between the fungal cells well and the rice plasma membrane can bind to chitin, and is able to suppress chitin-induced plant immune responses, including generation of reactive oxygen species and plant defense gene expression (Thomas et al, 2012).

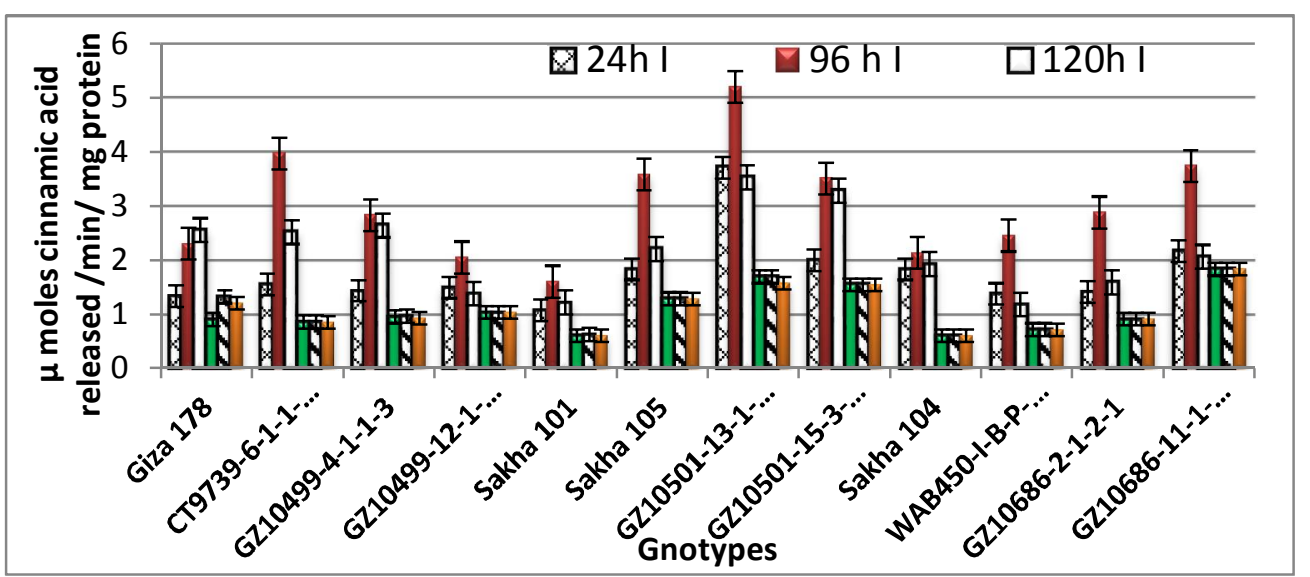

Fig. 3. Levels of PAL in leaves of rice genotypes 48,96 and $120 \mathrm{hr}$ after artificial inoculation with $P$. oryzae. The bar indicates standard error (SE \pm ) of mean $(n=3)$ at Duncan test $(P \leq 0.05=0.255)$ probability. 


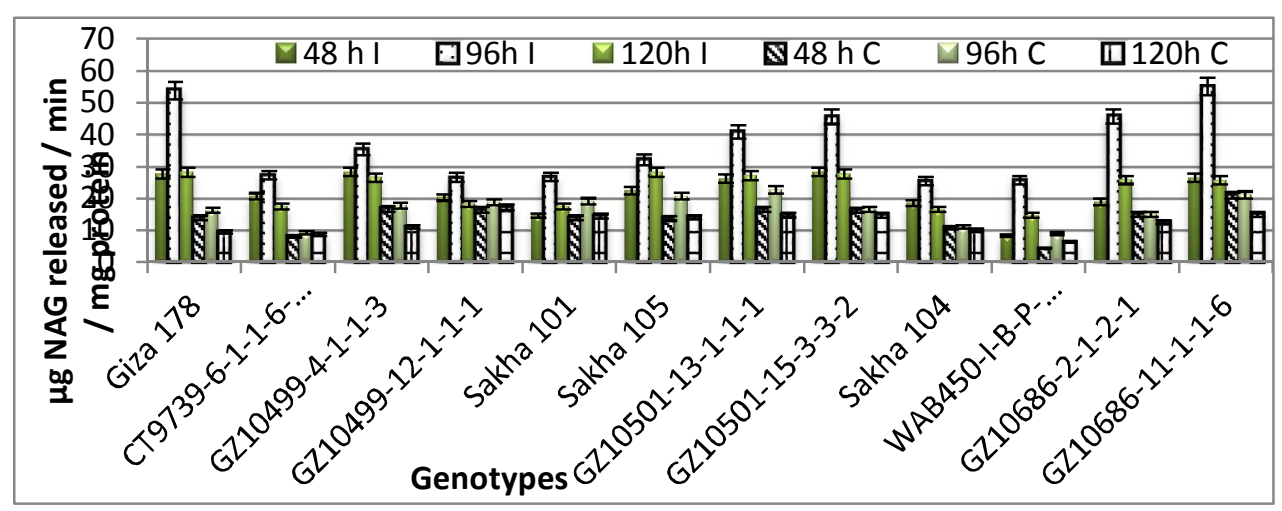

Fig. 4. Levels of chitinase activity in leaves of rice genotypes 48, 96 and 120 hr after artificial inoculation with $P$. oryzae. The bar indicates standard error $(S E \pm)$ of mean $(n=3)$ at Duncan test $(P \leq 0.05=7.23$ probability).

Shimizu et al. (2010) reported that Secreted LysM Protein1 considered a novel effector secreted by M. oryzae. In rice LysM Protein1 required for chitin cooperation to induced kinase Os-CERK1.

\section{Activity of defense-related Salicylic Acid (SA):}

The SA content of inoculated rice genotypes after $48 \mathrm{hr}$ ranged between 13.87 and $40.97 \mu \mathrm{g} / \mathrm{mg}$. SA content was higher in inoculated seedlings compared with uninoculated (Fig.5). Giza 178 (Resistant cultivar) proved to have the highest content of SA in inoculated and un-inoculated (40.97 and $35.28 \mu \mathrm{g} / \mathrm{mg}$ ) with the pathogen. There was no significant difference between Giza 178 and GZ10501-15-2-1-2 (R) in SA content. The low level of induction was recorded in inoculated Sakha 101 and 104 (13.87 and $14.9 \mu \mathrm{g} / \mathrm{mg}$, respectively) and un-inoculated $(7.15$ and $8.83 \mu \mathrm{g} / \mathrm{mg}$, respectively), blast susceptible rice cultivars. The most important role for SA is signaling the induction of defense responses for various plants after pathogen infection, and these responses include; induced local and systemic resistance disease, potentiation of host cell death, and the containment of pathogen spread. The effects of SA mediate may appear on increased defense gene expression, alterations in the activity or synthesis of certain enzymes, potentiation of several defense responses, and/or the generation of free radicals (Dempsey et al., 1999). 


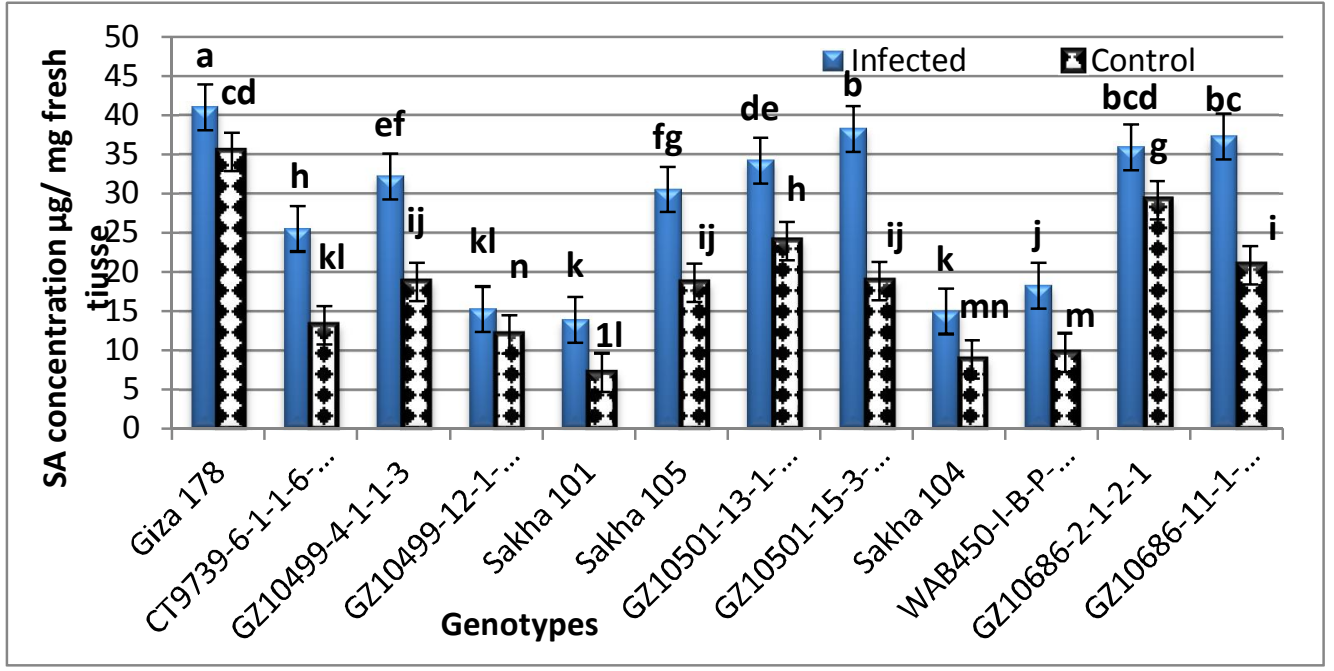

Fig. 5. Salicylic acid concentration in leaves of rice genotypes and after artificial inoculation with $P$. oryzae. The bar indicates standard error (SE \pm ) of mean $(n=3)$ in a column, means followed by a common letter are not significantly different at Duncan test with $\mathbf{P} \leq \mathbf{0 . 0 5}$ probability.

Salicylic acid (SA; 2-hydroxybenzoic acid) is one of many phenolic compounds that are synthesized by plants. Phenolic compounds may be involved in many important processes, including lignin and pigment biosynthesis, allelopathy, and the regulation of responses to abiotic and biotic stress (Métraux, 1993).

The activities of defense-related and antioxidant enzymes in resistant genotypes increased in association with $P$. grisea infection. This suggesting that resistant rice genotype has strong defense systems. In susceptible rice genotypes, the activities of defense-related and antioxidant enzymes were lower compared with resistant genotypes. These results could be effectively exploited to screen the rice genotypes for blast resistance.

\section{REFERENCE}

1. Agrawal, G. K.; N. S. Jwa; K. S. Han; V. P. Agrawal and R. Rakwal. 2003. Isolation of a novel rice PR4 type gene whose mRNA expression is modulated by blast pathogen attack and signaling components. Plant Physiology and Biochemistry, 41: 81-90. http://dx.doi.org/10.1016/S0981-9428(02)00012-8

2. Allam, A. I. and J. P. Hollis. 1972. Sulphide inhibition of oxidase in rice roots. Phytopathology, 62(3): 634-639.

3. Almagro, L.; Gomez Ros; L. V. Belchi-Navarro; S. Bru; R. Ros Barcelo and M. A.Pedreno. 2009. Class III peroxidases in plant defence reactions. Journal of Experimental Botany, 60: 377-390. http://dx.doi.org/10.1093/jxb/ern277 
4. Arafa, R. A. M. 2012. Studies on identification of the physiological races of the rice blast fungus by traditional and genetic methods. M.Sc. thesis, Plant Pathol. Dept., Fac. Agric., Kafrelsheikh Univ.

5. Atkins, J.G.; A. L. Robert; C. R. Adair; K. Goto; T. Kozako; R. Yanagida; Y. Yamada and S. Matsumoto. 1967. An international set of rice varieties for differentiating races of Pyricularia oryzae. Phytopathology, 57: 298-301.

6. Barna, B.; J. Fodor; B. D. Harrach; M.Pogany and Z. Kiraly. 2012. The Janus face of reactive oxygen species in resistance and susceptibility of plants to necrotrophic and biotrophic pathogens. Plant Physiology and Biochemistry, 59: 37-43. http://dx.doi.org/10.1016/j.plaphy.2012.01.014

7. Boller, T. 1988. Ethylene and the regulation of antifungal hydrolases in plants. Oxford Surveys of Plant Molecular and Cell Biology, 5:145-174.

8. Bonman, J. M.; G. S. Khush and R. J. Nelson. 1992. Breeding rice for resistance to pests. Annual Review of Phytopathology, 30, 507-528.

9. Campos, R.; H. Nonogaki; T.Suslow and M. S. Saltveit. 2004. Isolation and characterization of a wound inducible phenylalanine ammonia-lyase gene (LsPAL1) from Romaine lettuce leaves. Physiologia Plantarum, 121, 429- 438.

10. Campos, R.; H.Nonogaki; T. Suslow and M. S. Saltveit. 2004. Isolation and characterization of a wound inducible phenylalanine ammonia-lyase gene (LsPAL1) from Romaine lettuce leaves. Physiologia Plantarum, 121, 429- 438.

11. Chen, Y. C.; B. N. Kidd; L. C. Carvalhais and P. M. Schenk. 2014. Molecular defense responses in roots and the rhizosphere against Fusarium oxysporum. Plant Signaling \& Behavior, 9:(12) 977710. doi:10.4161/15592324.2014.977710]

12. Dempsey, A.; D'.Maris; J. Shah and F. K. Daniel. 1999. Salicylic Acid and Disease Resistance in Plants. Critical Reviews in Plant Sciences. 18. 547-575. $10.1080 / 07352689991309397$

13. Dempsey,A.; D. S. Jyoti; F. K. Daniel. 1999. Salicylic Acid and Disease Resistance in Plants. Critical Reviews in Plant Sciences, 18:547-575. $\underline{10.1080 / 07352689991309397 .}$

14. Divya B.; S. Robin; R. Rabindran; H. Manjunath; P. Valarmathi; A.J. Joel. 2014. Resistance reaction of gene introgressed lines against rice blast (Pyricularia oryzae) disease. Australasian Plant Pathology, 43: 177-191.

15. Dixon, R. A. 2001. Natural products and plant disease resistance. Nature, 411:843-847. http://dx.doi.org/10.1038/35081178

16. Duncan, M. R.T. 1955. Multiple rang and multiple F. test. Biometrics. 11: 1-42.

17. Fang, X. ; P. Snell, M.J. Barbetti1 and V. Lanoiselet. 2017. Rice varieties with resistance to multiple races of races of Magnaporthe oryzae offer opportunities to manage rice blast in Australia. Ann Appl Biol 170 : 160-169. 
18. Giri, A. P.; A. M. Harsulkar; A. G. Patankar; V. S.Gupta, , M. N. Sainani; V. V. Deshpande and P. K. Ranjekar. 1998. Association of induction of protease and chitinase in chickpea roots with resistance to Fusarium oxysporum f. sp. ciceri. Plant Pathology, 47, 693-699.

19. Giri, A. P.; A. M.Harsulkar; A. G.Patankar; V. S.Gupta; M. N. Sainani; V. V.Deshpande and P. K. Ranjekar. 1998. Association of induction of protease and chitinase in chickpea roots with resistance to Fusarium oxysporum f. sp. ciceri. Plant Pathology, 47, 693-699.

20. Goupy, P.; M. Hugues; P. Boivin and M. J.Amiot. 1999. Antioxdiant composition and activity of barley (Hordeum vulgare) and malt extracts and of isolated phenolic compound. J. Sci., Food Agric., 79:1625-1635.

21. Hsieh, L. S.; G. T., Ma; C. C. Yang and P. D. Lee. 2010. Cloning, expression, site-directed mutagenesis and immunolocalization of phenylalanine ammonia-lyase in Bambusa oldhamii. Phytochemistry, 71: 1999-2009. http://dx.doi.org/10.1016/j.phytochem.2010.09.019

22. IRRI. 1996. International Rice Research Institute. Standard Evaluation System for Rice, 3rd ed. IRRI, Los Banos, Philippines.

23. Jones, J. D. G. and J. Dangl. 2006. The plant immune system. Nature, 444:323329. http://dx.doi.org/10.1038/nature05286

24. Kalboush, Zeinab,A.A. 2007. Integrated management of brown spot disease of rice in Egypt. Ms. Thesis, Faculty of Agric., Kafr El-Sheikh Univ. Egypt.

25. Kini, K. R.; N. S Vasanthi and H. S. Shetty. 2000. Induction of $\beta-1,3-$ glucanase in seedlings of pearl millet in response to infection by Sclerospora graminicola. European J Plant Pathology, 106, 267-274.

26. Kini, K. R.; N. S. Vasanthi and H. S. Shetty. 2000. Induction of $\beta-1,3$-glucanase in seedlings of pearl millet in response to infection by Sclerospora graminicola. European Journal of Plant Pathology, 106, 267-274. http://dx.doi.org/10.1023/A:1008771124782.

27. Liang, Y. C.; Q.Chen; Q. Liu; W. H. Zhang and R. X. Ding. 2003. Exogenous silicon ( $\mathrm{Si}$ ) increases antioxidant enzyme activity and reduces lipid peroxidation in roots of saltstressed barley (Hordeum vulgare L.). J. Plant Physiology, 160, 11571164.

28. Métraux, .J.P and I. Raskin. 1993. Role of phenolics in plant disease resistance. In: Chet I, editor. Biotechnology in plant disease control. New York: Wiley; p. 191-209.

29. Moldenhauer, K.A.K., A. O. Bastawisi and F.N. Lee. 1992. Inheritance of resistance in rice to race IB-49 and IC-17 of Pricularia grisea rice blast. Crop Sci. 32: 584- 588. 
30. Nakona, Y. and K. Asada. 1981. Hydrogen peroxide is scavenged by ascorbic specific peroxidase in spinach chloroplasts. Plant and Cell Physiology, 22, 868880.

31. Nikraftar, F.; P. Taheri; M. Falahati Rastegara and S. Tarighi. 2013. Tomato partial resistance to Rhizoctonia solani involves antioxidative defense mechanisms. Physiological and Molecular Plant Pathology, 81: 74-83. http://dx.doi.org/10.1016/j.pmpp.2012.11.004.

32. Osman, Z.H., E.A.S. Badr, M.R. Sehly, S.M. El-Wahsh, E.A. Salem and Nagwa M. A. Mahmoud. 2002. Role of Silicon in the management of some rice diseases. J. Agric. Sci. Mansoura Unvi., 27 (3): 1459-1470.

33. Panda, S. K. 2007. Chromium-mediated oxidative stress and ultrastructural changes in root cells of developing rice seedlings. J. Plant Physiology, 164,14191428.

34. Rahman, A.; W. Uddin and N. G. Wenner. 2014. Induced systemic resistance responses in perennial ryegrass against Magnaporthe oryzae elicited by semipurified surfactin lipopeptides and live cells of Bacillus amyloliquefaciens. Mole Plant Pathology. doi:10.1111/ mpp.12209.

35. Reid, J. D. and Z. Ogrud. 1981. Chitinase-overproducing mutants of Serratia marcescens. Applied Environmental Microbiology, 41: 664-669.

36. Saikia, R.; R. Kumar; D.K. Arora; D.K. Gogoi and P. Azad. 2006. Pseudomonas aeruginosa inducing rice resistance against Rhizoctonia solani: production of salicylic acid and peroxidases, Folia. Microbiol. 51:375-380.

37. Scheuermann K.K.; J.V.Raimondi; R. Marschalek; A. De Andrade and E. Wickert 2012. Magnaporthe oryzae genetic diversity and Its outcomes on the search for durable resistance. INTECH Open Access Publisher.

38. Sedeek, S.E.M. and S.M. Elwahsh. 2015. Performance of some agronomic traits of selected rice breeding lines and its reaction to blast disease. Agric.Res.Kafrelsheikh.univ.,41(1):167-180.

39. Sehly, M. R.; Osman Z. H.; Salem E. A.; Badr E. A. S. and El-Wahsh S. 2000. Proceeding of the Fourth National Rice Research and Development Program Workshop, 12-13(2): 73-115.

40. Sehly, M. R.; S. M. EL-Wahsh; M. M. EL-Malky ; E. A. S. Badr; R. A. S. EL-Shafey and I. R. Aidy. 2008. Evaluation of certain Egyptian rice cultivars to blast disease incidence during fourteen years. Egyptian Journal of Agriculture Science, Mansura Univ., 33(4): 2643-2657.

41. Sehly, M. R.; Z. H. Osman; E. A. Salem; I. R. Aidy and A. E. Draz. 1993. Multi location test for rice blast reaction in relation to race distribution. Egyptian Journal of Applied Science, 8(2):136-152. 
42. Shabana, Y. M.1; S. M. El-Wahsh; A. F. Abdelkhalik; S. A. Fayzalla1 and A. A. Hassan. 2013. Physiological races of rice blast and host resistant genes under Egyptian condition. J. Plant Prot. and Path., Mansoura Univ., Vol. 4 (8): 709 720.

43. Shimizu, T.; T.Nakano; D. Takamizawa; Y. Desaki; N. Ishii- Minami; Y. Nishizawa and N. Shibuya. 2010. Two LysM receptor molecules, CEBiP and OsCERK1, cooperatively regulate chitin elicitor signaling in rice. The Plant Journal, 64: 204214. http://dx.doi.org/10.1111/tpj.2010.64.issue-2

44. Srivastava, S.K. 1987. Peroxidase and polyphenol-oxidase in Brassica juncea plants infected with Macrophomina phaseolina (Tassi: Goid of and their implication in disease resistance. Phytopathology, 120: 249-254.

45. Staskawicz, B. J.; F. M.Ausubel; B. J.Baker; J. G. Ellis and J.D.C.Jones. 1997. Molecular genetics of plant disease resistance. Science, 268:661-667.

46. Thomas A.; Y. Nishizawa; N. Shibuya; B. P.H.J. Thomma and N. J. Talbot. 2012. Effector-Mediated Suppression of Chitin-triggered Immunity by Magnaporthe oryzae Is Necessary for Rice Blast disease. Plant and M. D. Fricker. 2014. Robust anti-oxidant defenses in the rice blast fungus Magnaporthe oryzae confer tolerance to the host oxidative burst. New Phytologist, 201:556-573. http://dx.doi.org/10.1111/nph.12530

47. Torres, M. A.; J. D. G. Jones and J. L. Dang. 2006. Reactive oxygen species signaling in response to pathogens. Plant Physiology, 141, 373-378. http://dx.doi.org/10.1104/pp.106.079467

48. van Loon, L. C.; M. Rep, and C. M. Pieterse. 2006. Significance of inducible defense-related proteins in infected plants. Annual Review of Phytopathology, 44:135-162. http://dx. doi.org/10.1146/annurev.phyto.44.070505.143425.

49. Wang, Z.; J.N. Rutger and Y. Xia. 2007. Rapid survey for presence of a blast resistance gene Pi-ta in rice cultivars using the dominant DNA markers derived from portions of the Pi-ta gene. Plant Breeding 126,36-42.

50. Yamaguchii, M.; H. Saitoh and T. Higashi. 1998. Effect of varietals field resistance for control of rice blast. Advances in rice blast research, 197-202. Kluwer Academic Publishers, Netherlands.

51. Zhang, J. T.; G. M., Duan, and Z. Y. Yu. 1987. Relationship between Phenylalanine ammonia lyase (PAL) activity and resistance to rice blast. Plant Physiology Communications, 6: 34-37. 


\section{مقاومة طرز وراثية من الأرز لفطر اللفحه و \\ التغيرات البيوكيميائية المصاحبه}

$$
\text { زينب عبد النبى كلبوش }
$$

قسم بحوث أمراض الأرز - معهُ بحوث أمراض النباتات - مركز البحوث الزراعية - الجيزة

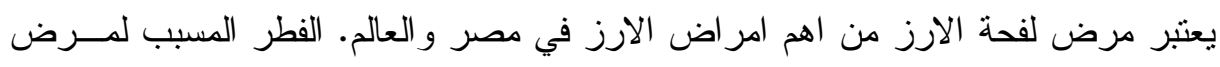

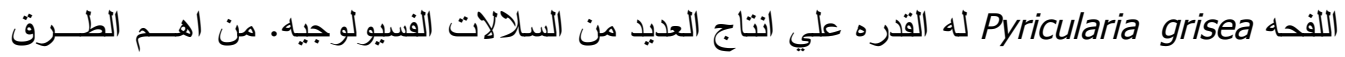

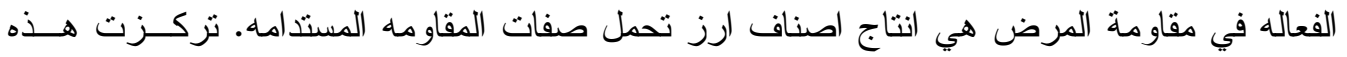
الدر اسه علي تعريف 20 عزله من الفطر الممرض وتقيبم 21 نمط ور اثي للعدوي بالفطر المســبب. و ايضا در اسة التغير ات الكيميائية الحيوية بعد العدوي بالفطر الممرض. قسم تعريف السلالات الـي بـي

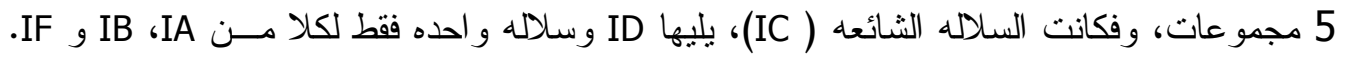
لوحظ في تقييم الطرز الور اثثه في الارز ان المجموعه الاولي و الثانيه مقاومه للاصـابه بالمرض، اما المجموعه الثالثه تزواحت المقاومه 70 الي 75 \% . التغير ات الكيميائية الحيوية تم در استها بو اسطة

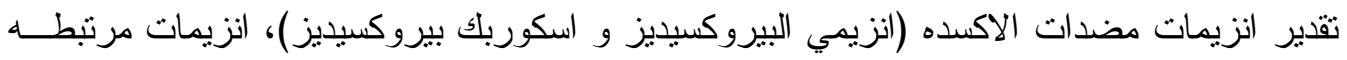
بالدفاع ( انزيمي الفينيل الالانين امونياليز و الكيتين) وحمض السلسيلك. زادت الانزيمات المقدره بعد 96 من العدوي بالفطر المسبب وبعد ذلك انخفضت. محتوي بادرات الارز الملقحه بالفطر المســبب من الانزيمات اعلي من الغير ملقحه. وجد ان اعلي محتوي لحمص السلسيلك في صنف الارز جيزه 
